DOI: https://doi.org/10.36376/bmj.v6i2

Disubmit 6 Agustus 2019

Diterima 30 Desember 2019

\title{
HUBUNGAN OBESITAS SENTRAL DAN AKTIVITAS FISIK DENGAN KEJADIAN DIABETES MELITUS TIPE 2 DI PUSKESMAS III DENPASAR UTARA
}

\author{
THE RELATION OF CENTRAL OBESITY AND \\ PHYSICAL ACTIVITY WITH THE INCIDENCE OF \\ TYPE 2 DIABETES MELLITUS IN NORTH DENPASAR \\ HEALTH CENTER III
}

\author{
Ni Wayan Trisnadewi ${ }^{1}$, Ni Luh Widarsih ${ }^{2}$, Theresia Anita Pramesti ${ }^{3}$. \\ ${ }_{1,2,3}$ Program Studi Keperawatan STIKes Wira Medika Bali ${ }^{1,2,3}$
}

\begin{abstract}
ABSTRAK
Diabetes melitus tipe 2 merupakan kasus diabetes yang paling sering terjadi dan disebabkan oleh beberapa faktor seperti obesitas sentral dan aktivitas fisik. Tujuan dari penelitian ini adalah mengetahui hubungan obesitas sentral dan aktivitas fisik dengan kejadian diabetes melitus tipe 2 di Puskesmas III Denpasar Utara. Penelitian ini merupakan penelitian deskriptif korelasional dengan pendekatan cross sectional. Penentuan sampel menggunakan teknik purposive sampling dengan 51 responden. Hasil uji Lambda pada hubungan obesitas sentral dan kejadian diabetes melitus tipe 2 didapatkan sekitar 29 responden dengan diabetes melitus tipe 2 dan mengalami obesitas sentral dengan nilai $\mathrm{p}=0,031(\mathrm{p}<0,05)$, maka $\mathrm{H}_{0}$ ditolak yang berarti terdapat hubungan obesitas sentral dengan kejadian diabetes melitus tipe 2 di Puskesmas III Denpasar Utara dengan nilai $r=0,529$ yang menunjukkan korelasi sedang dan arah korelasi positif. Hasil uji Lambda pada hubungan aktivitas fisik dan kejadian diabetes melitus tipe 2 didapatkan hasil 27 responden dengan diabetes melitus tipe 2 dan memiliki aktivitas rendah dengan nilai $\mathrm{p}=0,04(\mathrm{p}<0,05)$ maka $\mathrm{H}_{0}$ ditolak yang berarti terdapat hubungan aktivitas fisik dengan kejadian diabetes melitus tipe 2 di Puskesmas III Denpasar Utara dengan nilai $r=0,529$ yang memiliki korelasi sedang dan arah korelasi positif. Penurunan adipose viseral pada obesitas sentral dan aktivitas fisik tinggi dapat meningkatkan sensitifitas reseptor insulin.
\end{abstract}

Kata kunci: Obesitas sentral, aktivitas fisik, diabetes melitus tipe 2

\section{ABSTRACT}

Type 2 diabetes mellitus is a diabetes that most occurs and can caused by several factors such as central obesity and physical activity. This study aimed to determine the relation of central obesity and physical activity with the incidence of type 2 diabetes mellitus in North Denpasar Health Center III. This research used descriptive correlation with cross sectional approach, conducted with 51 respondents used purposive sampling. Lambda test results on relation of central obesity and incidence of type 2 diabetes mellitus showed that 29 respondents with type 2 diabetes mellitus and central obesity obtained $p$ value $=0.031$ 
BMJ. Vol 6 No 2, 2019: 119-129

DOI: $\underline{\text { https://doi.org/10.36376/bmj.v6i2 }}$

$(p<0.05)$, that means $H_{0}$ was rejected and there's relation between central obesity and incidence of type 2 diabetes mellitus with $r$ value $=0.529$. Lambda test results on the relation of physical activity and incidence of type 2 diabetes mellitus showed 27 respondents with type 2 diabetes mellitus and low physical activity obtained $p$ value $=0.04(p<0.05)$ that means $H_{0}$ was rejected there's relation between physical activity and incidence of type 2 diabetes mellitus with $r$ value $=0.529$. The result indicated a moderate and positive correlation. The decreased of visceral adipose in central obesity and high physical activity can increase the sensitivity of insulin receptors.

Keyword: Central obesity, physical activity, type 2 diabetes mellitus

\begin{tabular}{ll}
\hline Alamat Korespondensi & $\begin{array}{l}\text { : STIKes Wira Medika Bali Jln. Kecak No. 9A Gatot Subroto Timur } \\
\text { Denpasar }\end{array}$ \\
Email & trisnawika09@gmail.com \\
\hline
\end{tabular}

\section{PENDAHULUAN}

Peningkatan sosial ekonomi, pelayanan kesehatan masyarakat, dan perubahan gaya hidup menyebabkan pergeseran pola penyakit dari penyakit menular menjadi penyakit tidak menular. Salah satu penyakit tidak menular yang meningkat di masyarakat adalah Diabetes Melitus (DM). Berdasarkan data dari International Diabetes Federation (2017), jumlah penderita DM pada tahun 2017 pada rentang usia 20-79 tahun sebanyak 424,9 juta jiwa atau sekitar $8,8 \%$ dari penduduk dunia. Penderita diabetes melitus $80 \%$ berasal dari negara berkembang salah satunya adalah Indonesia.Data di Indonesia, terdapat 10,3 juta jiwa penderita diabetes melitus dan Indonesia merupakan negara urutan ke-6 terbanyak yang menderita. Berdasarkan data Dinas Kesehatan Provinsi Bali, terdapat 10.465 penderita diabetes melitus pada tahun 2015, 12.072 orang pada tahun 2016 dan 11.298 orang pada tahun 2017. Salah satu daerah di Bali yang memiliki angka insiden diabetes tinggi yaitu Kota Denpasar. Menurut data Dinas Kesehatan Kota Denpasar, angka kejadian diabetes melitus tahun 2016 sebanyak 2148 orang dan meningkat pada tahun 2017 menjadi 3384. Salah satu Puskesmas di Kota Denpasar yaitu Puskesmas III Denpasar Utara memiliki insiden diabetes melitus tipe 2 terbanyak dengan angka kunjungan sebanyak 172 orang pada tahun 2016 dan 232 orang pada tahun 2017.

Menurut International Diabetes Federation (IDF) (2017), sebanyak 90\% kasus diabetes melitus merupakan kasus diabetes melitus tipe 2 . Tingginya angka kejadian diabetes melitus terutama tipe 2 disebabkan oleh beberapa faktor seperti faktor keturunan, usia, riwayat BBLR atau bayi lahir kurang dari 2500 gram, jenis kelamin, obesitas (berdasarkan IMT maupun berdasarkan lingkar perut atau obesitas sentral), dislipidemia, aktivitas fisik yang kurang, dan diet tidak sehat (Perkumpulan Endrokinologi Indonesia, 2015). Salah satu faktor risiko yang menyebabkan diabetes adalah obesitas. Menurut Kementerian Kesehatan Republik Indonesia (2014), pasien obesitas sentral yang juga menderita diabetes melitus di Indonesia sebesar 26,6\%. Peningkatan asam lemak bebas akan merangsang pengeluaran hormon-hormon adipositokin seperti leptin, Tumor Necrosis Faktor $\alpha$ (TNF- $\alpha$ ), Interleukin-6 (IL-6), resistin dan penurunan adinopektin. Pengeluaran 
DOI: $\underline{\text { https://doi.org/10.36376/bmj.v6i2 }}$

hormon adipositokin mengakibatkan peningkatan glukoneogenesis, menghambat reseptor insulin dan menghambat ambilan glukosa otot yang dapat menyebabkan terjadinya resistensi insulin serta nantinya dapat menyebabkan diabetes melitus (Black \& Hawks, 2008). Aktivitas fisik juga merupakan salah satu faktor risiko diabetes melitus tipe 2, selain obesitas sentral (Perkumpulan Endrokinologi Indonesia, 2015). Tingkat aktivitas fisik yang rendah, mempengaruhi terjadinya diabetes tipe 2 . Kurangnya aktivitas fisik juga menyebabkan penurunan aliran darah dan sedikit jala-jala kapiler yang terbuka sehingga menyebabkan berkurangnya ketersediaan reseptor insulin dan reseptor menjadi lebih pasif (Sudoyo, Setiyohadi, Alwi, Simadibrata \& Setiati, 2009).

Diabetes melitus yang tidak ditan gani dapat menyebabkan terjadinya komplikasi. Diabetes melitus tipe 2 dapat menimbulkan komplikasi akut maupun kronik. Upaya pencegahan dan penanggulan diabetes melitus telah dilakukan. Menurut Perkumpulan Endrokinologi Indonesia (PERKENI) (2015), pemerintah telah mencanangkan program penanggulangan diabetes melitus yang disebut 4 pilar penatalaksanaan DM meliputi perencanaan diet, aktifitas fisik atau olahraga, edukasi dan intervensi farmakologi namun, hal tersebut masih belum dapat menanggulangi kejadian diabetes di Indonesia dikarenakan tidak disiplinnya penderita atau pasien diabetes dalam melakukan penatalaksanaan tersebut.

Berdasarkan data tersebut dapat dilihat bahwa terdapat berbagai macam komplikasi dan upaya pencegahan diabetes melitus yang masih belum tertangani. Peran serta pemerintah dan kesadaran individu yang mengalami penyakit diabetes melitus sangat berperan penting dalam penanggulangan diabetes melitus. Selain hal tersebut, mengetahui faktor risiko seperti obesitas sentral dan aktivitas fisik juga sangat perlu untuk diketahui oleh penderita diabetes agar derajat kesehatan masyarakat semakin meningkat. Berdasarkan data tersebut peneliti tertarik untuk melakukan penelitian yang berjudul "Hubungan obesitas sentral dan aktivitas fisik dengan kejadian diabetes melitus tipe 2 di Puskesmas III Denpasar Utara".

\section{METODE PENELITIAN}

Dalam penelitian ini peneliti menggunakan rancangan deskriptif korelasional. Penelitian ini menggunakan metode pendekatan cross-sectional yang menekankan waktu pengukuran variabel independen dan dependen hanya satu kali pada satu saat (Nursalam, 2017). Penelitian ini dilaksanakan di Puskesmas III Denpasar Utara tanggal 11 Oktober - 11 November 2018. Populasi pada penelitian ini adalah pasien yang berobat di Puskesmas III Denpasar Utara sebanyak 58 orang. Besar sampel dalam penelitian ini berjumlah 51 responden. Sampel dalam penelitian diambil menggunakan teknik non probability sampling yaitu purposive sampling. Variabel bebas dalam penelitian ini adalah obesitas sentral dan aktivitas fisik. Variabel terikat dalam penelitian ini adalah diabetes mellitus tipe 2.

Penelitian ini menggunakan pita ukur atau meteran untuk mengukur lingkar perut dan kuesioner Global Physical Activity Questionnaire (GPAQ) yang diadopsi dari World Health Organization (WHO) dan berisi 16 pertanyaan untuk mengetahui riwayat aktivitas fisik responden.

Analisa univariat digunakan dalam mengidentifikasi obesitas sentral, aktivitas fisik dan kejadian diabetes melitus tipe 2 di Puskesmas III Denpasar Utara yang digambarkan dalam bentuk jumlah (frekuensi) dan persentase (\%). Pada 
penelitian ini data dianalisis dengan menggunakan statistik deskriptif, kemudian hasilnya disajikan dalam bentuk narasi dan tabel distribusi frekuensi. Uji bivariat yang digunakan dalam penelitian ini adalah uji Lambda untuk mengetahui hubungan antara obesitas sentral dengan kejadian diabetes melitus tipe 2 dan hubungan aktivitas fisik dengan kejadian diabetes melitus tipe 2 di Puskesmas III Denpasar Utara dengan ketentuan jika nilai $\mathrm{p}<0.05$ maka dapat disimpulkan bahwa terdapat korelasi yang signifikan antara variabel yang dihubungkan begitu juga sebaliknya.

\section{HASIL}

\section{HASIL DAN PEMBAHASAN}

\section{Obesitas sentral}

Tabel 4.3

Distribusi Responden Berdasarkan Obesitas Sentral di Puskesmas III Denpasar Utara

\begin{tabular}{lccc}
\hline No & $\begin{array}{c}\text { Obesitas } \\
\text { sentral }\end{array}$ & Frekuensi (n) & Persentase (\%) \\
\hline 1. & Obesitas & 32 & 62,7 \\
2. & sentral & 19 & 37,3 \\
\hline & Normal & 51 & 100 \\
\hline
\end{tabular}

Berdasarkan tabel di atas, dari 51 responden didapatkan bahwa sebagian besar responden mengalami obesitas sentral yaitu sebanyak 32 responden $(62,7 \%)$.

\section{Aktivitas Fisik}

Tabel 4.4

Distribusi Responden Berdasarkan Aktivitas Fisikdi Puskesmas III Denpasar Utara

\begin{tabular}{cccc}
\hline No & Aktivitas Fisik & Frekuensi (n) & Persentase (\%) \\
\hline 1. & Rendah & 29 & 56,9 \\
2. & Sedang & 21 & 41,1 \\
3. & Tinggi & 1 & 2,0 \\
\hline & Jumlah & 51 & 100 \\
\hline
\end{tabular}

Berdasarkan interpretasi tabel di atas, dari 51 responden didapatkan bahwa sebagian besar memiliki riwayat aktivitas fisik rendah yaitu sebanyak 29 responden $(56,9 \%)$. 
BMJ. Vol 6 No 2, 2019: 119-129

ISSN : 2615-7047

DOI: $\underline{\text { https://doi.org/10.36376/bmj.v6i2 }}$

Diabetes Melitus tipe 2

Tabel 4.5

Distribusi Responden Berdasarkan Kejadian Diabetes Melitus Tipe 2 di

Puskesmas III Denpasar Utara

\begin{tabular}{cccc}
\hline No & $\begin{array}{c}\text { Kejadian } \\
\text { Diabetes Melitus } \\
\text { Tipe 2 }\end{array}$ & $\begin{array}{c}\text { Frekuensi } \\
\text { (n) }\end{array}$ & $\begin{array}{c}\text { Persentas } \\
\text { e (\%) }\end{array}$ \\
\hline 1. & DM tipe 2 & 34 & 66,7
\end{tabular}

2. Tidak DM tipe 2

$17 \quad 33,3$

\begin{tabular}{lll} 
Jumlah & 51 & 100 \\
\hline
\end{tabular}

Berdasarkan tabel di atas, dari 51 responden didapatkan bahwa sebagian besar responden mengidap diabetes melitus tipe 2 sebanyak 34 responden $(66,7 \%)$.

\section{Hubungan obesitas sentral dengan kejadian diabetes melitus tipe 2 di Puskesmas III Denpasar Utara}

Tabel 4.6

Analisis Bivariat Hubungan Obesitas Sentral dengan Kejadian Diabetes Melitus

Tipe 2 di Puskesmas III Denpasar Utara

\begin{tabular}{|c|c|c|c|c|c|c|c|c|}
\hline \multirow{3}{*}{$\begin{array}{c}\text { Obesitas } \\
\text { sentral }\end{array}$} & \multicolumn{4}{|c|}{ Kejadian DM Tipe 2} & \multirow{2}{*}{\multicolumn{2}{|c|}{$\mathrm{Jml}$}} & \multirow{3}{*}{$P$} & \multirow{3}{*}{$\mathrm{R}$} \\
\hline & \multicolumn{2}{|c|}{ DM Tipe 2} & \multicolumn{2}{|c|}{ Tidak DM tipe 2} & & & & \\
\hline & $\mathrm{F}$ & $\%$ & $\mathrm{~F}$ & $\%$ & $f$ & $\%$ & & \\
\hline $\begin{array}{c}\text { Obesitas } \\
\text { sentral }\end{array}$ & 29 & 56,9 & 3 & 5,9 & 32 & 62,7 & 0,031 & 0,529 \\
\hline Normal & 5 & 9,8 & 14 & 27,9 & 19 & 37,3 & & \\
\hline $\mathrm{Jml}$ & 34 & 66,7 & 17 & 33,3 & 51 & 100 & & \\
\hline
\end{tabular}

Berdasarkan tabel di atas, didapatkan data bahwa responden dengan diabetes melitus tipe 2 sebagian besar mengalami obesitas sentral sebanyak 29 responden $(56,9 \%)$.

Hasil analisis bivariat menggunakan uji Lambda dan diperoleh nilai $\mathrm{p}=0,031$ karena nilai $\mathrm{p}<\alpha(0,05)$, maka $\mathrm{H}_{0}$ ditolak. Hal ini berarti bahwa ada hubungan yang bermakna antara obesitas sentral dengan kejadian diabetes melitus tipe 2 di Puskesmas III Denpasar Utara. Kuat lemahnya korelasi dilihat dari nilai r yaitu 0,529 nilai tersebut menunjukkan korelasi yang sedang antara variabel obesitas sentral dengan kejadian diabetes melitus tipe 2. Nilai koefisien korelasi bertanda positif ini menunjukkan bahwa semakin obesitas sentral responden maka semakin besar risiko mengalami diabetes melitus tipe 2 di Puskesmas III Denpasar Utara dan begitu juga sebaliknya. 
BMJ. Vol 6 No 2, 2019: 119-129

ISSN : 2615-7047

DOI: $\underline{\text { https://doi.org/10.36376/bmj.v6i2 }}$

\section{Hubungan aktivitas fisik dengan kejadian diabetes melitus tipe 2 di Puskesmas III Denpasar Utara}

Tabel 4.7

Analisis Bivariat Hubungan Aktivitas Fisik dengan Kejadian Diabetes Melitus

Tipe 2 di Puskesmas III Denpasar Utara

\begin{tabular}{|c|c|c|c|c|c|c|c|c|}
\hline \multirow{3}{*}{$\begin{array}{c}\text { Aktivitas } \\
\text { Fisik }\end{array}$} & \multicolumn{4}{|c|}{ Kejadian DM Tipe 2} & \multirow{2}{*}{\multicolumn{2}{|c|}{ Jumlah }} & \multirow{3}{*}{$P$} & \multirow{3}{*}{$\mathrm{R}$} \\
\hline & \multicolumn{2}{|c|}{ DM Tipe 2} & \multicolumn{2}{|c|}{ Tidak DM tipe 2} & & & & \\
\hline & $\mathrm{F}$ & $\%$ & $\mathrm{~F}$ & $\%$ & $\mathrm{f}$ & $\%$ & & \\
\hline Rendah & 27 & 52,9 & 2 & 3,9 & 29 & 56,9 & & \\
\hline Sedang & 6 & 11,8 & 15 & 29,4 & 21 & 41,2 & 0,041 & 0,529 \\
\hline Tinggi & 1 & 2,0 & & & 1 & 2,0 & & \\
\hline $\mathrm{Jml}$ & 34 & 66,7 & 17 & 33,3 & 51 & 100 & & \\
\hline
\end{tabular}

Berdasarkan tabel di atas, didapatkan bahwa responden dengan diabetes melitus tipe 2 sebagian besar memiliki aktivitas fisik rendah yaitu 27 responden $(52,9 \%)$. Hasil analisis bivariat menggunakan uji Lambda dan diperoleh nilai $\mathrm{p}=0,041$ karena nilai $\mathrm{p}<\alpha(0,05)$, maka $\mathrm{H}_{0}$ ditolak. Hal ini berarti bahwa ada hubungan yang bermakna antara aktivitas fisik dengan kejadian diabetes melitus tipe 2 di Puskesmas III Denpasar Utara. Kuat lemahnya korelasi dilihat dari nilai r yaitu 0,529 yang menunjukkan korelasi sedang antara variabel aktivitas fisik dengan kejadian diabetes melitus tipe 2. Nilai koefisien korelasi bertanda positif ini menunjukkan bahwa semakin rendah aktivitas fisik responden maka semakin besar risiko terkena diabetes melitus tipe 2 di Puskesmas III Denpasar Utara dan begitu juga sebaliknya.

\section{PEMBAHASAN}

\section{Obesitas Sentral}

Berdasarkan penelitian yang dilakukan di Puskesmas III Denpasar Utara didapatkan data bahwa dari 51 responden sebagian besar responden mengalami obesitas sentral yaitu sebanyak 32 orang $(62,7 \%)$. Hasil penelitian ini sesuai dengan penelitian yang dilakukan oleh Widastra (2014) yang menunjukkan dari 222 orang responden, 114 orang mengalami obesitas sentral $(51,4 \%)$ dari seluruh responden.

Responden sebagian besar mengalami obesitas sentral disebabkan karena beberapa faktor salah satunya adalah usia. Pada penelitian ini, responden paling banyak berada pada kisaran usia 41-50 tahun yaitu sebanyak 24 responden $(47,1 \%)$. Adanya proses penuaan menyebabkan berkurangnya kemampuan sel $\beta$ pulau Langerhans pankreas dalam memproduksi insulin diiringi timbulnya dampak gaya hidup di waktu berusia muda (remaja dan produktif), sehingga meningkatkan resiko terserang diabetes melitus tipe 2. Gaya hidup yang tidak sehat serta tidak melakukan cek kesehatan rutin, pada saat usia muda membuat seseorang mudah terserang diabetes mellitus di usia pertengahan dewasa (Trisnawati \& Soedijono, 2013). Selain usia, jenis kelamin juga merupakan faktor resiko dari obesitas sentral. Dalam penelitian ini, didapatkan data bahwa sebagian besar responden berjenis kelamin perempuan yaitu sebanyak 33 responden $(64,7 \%)$ sementara responden laki-laki sebanyak 18 responden (35,3\%). Menurut Flegal, Carrol, Ogden, \& Curtin (2010), 
DOI: https://doi.org/10.36376/bmj.v6i2

wanita memiliki risiko lebih tinggi mengalami obesitas sentral dibandingkan lakilaki setelah usia 45 tahun. Hal tersebut disebabkan karena seiring bertambahnya usia, efek menopouse pada perempuan akan meningkatkan kandungan lemak tubuh, terutama distribusi lemak tubuh pusat.

\section{Aktivitas Fisik}

Berdasarkan penelitian yang dilakukan di Puskesmas III Denpasar Utara, dari 51 responden didapatkan bahwa sebagian besar memiliki riwayat aktivitas fisik rendah yaitu sebanyak 29 responden $(56,9 \%)$ dan riwayat aktivitas tinggi sebanyak 1 orang $(2 \%)$. Hasil penelitian ini sesuai dengan penelitian yang dilakukan oleh Dafriani (2016) yang menyatakan bahwa dari 39 responden, 26 diantaranya memiliki riwayat aktivitas fisik yang rendah $(53,1 \%)$.

Menurut Salim (2014), Pola hidup sedentary biasa diterapkan saat ini seperti kebiasaan menonton televisi, menonton dan bermain handphone dalam waktu yang lama selama berjam-jam yang diselingi dengan mengonsumsi makanan. Pekerjaan yang mengharuskan duduk berjam-jam didepan komputer juga menjadi salah satu pemicu aktivitas yang rendah. Hal ini sejalan dengan pernyataan Rusyadi (2017) bahwa kemajuan teknologi berdampak pada berkurangnya aktivitas fisik seharihari. Menurut Kronenberg (2008), aktivitas fisik yang dilakukan oleh seseorang akan mempengaruhi kadar gula darahnya. Peningkatan penggunaan glukosa oleh otot akan meningkat saat seseorang melakukan aktivitas fisik yang tinggi. Hal tersebut disebabkan karena glukosa endogen akan ditingkatkan untuk menjaga agar kadar gula di dalam darah tetap seimbang. Pada keadaan normal, keseimbangan kadar gula darah tersebut dapat dicapai oleh berbagai mekanisme dari sistem saraf, regulasi glukosa dan keadaan hormonal.

\section{Hubungan Obesitas Sentral dengan Kejadian Diabetes Melitus Tipe 2}

Berdasarkan penelitian ini responden dengan diabetes melitus tipe 2 sebagian besar mengalami obesitas sentral sebanyak 29 responden (56,9\%). Hasil analisis bivariat menggunakan uji Lambda dan diperoleh nilai $\mathrm{p}=0,031$ karena nilai $\mathrm{p}<\alpha$ $(0,05)$, maka $\mathrm{H}_{0}$ ditolak. Hal ini berarti bahwa ada hubungan yang bermakna antara obesitas sentral dengan kejadian diabetes melitus tipe 2 di Puskesmas III Denpasar Utara. Kuat lemahnya korelasi dilihat dari nilai $r$ yaitu 0,529 nilai tersebut menunjukkan korelasi yang sedang antara variabel obesitas sentral dengan kejadian diabetes melitus tipe 2. Nilai koefisien korelasi bertanda positif ini menunjukkan bahwa semakin obesitas sentral responden maka semakin besar risiko mengalami diabetes melitus tipe 2 di Puskesmas III Denpasar Utara dan begitu juga sebaliknya.

Hasil penelitian ini sesuai dengan penelitian yang dilakukan oleh Susilawati, Muljati dan Krisnawati (2011) yang menyatakan bahwa terdapat hubungan antara obesitas sentral dan diabetes melitus tipe 2. Obesitas sentral dapat berisiko menyebabkan diabetes melitus sebesar 2,26 kali dari pada yang tidak obesitas sentral.

Menurut Black \& Hawks (2008), obesitas sentral mengakibatkan pelepasan asam lemak bebas ke dalam sirkulasi darah. Hal tersebut terjadi karena vena porta yang merupakan saluran darah tunggal bagi jaringan adiposa dan berhubungan langsung dengan hati. Mobilisasi lemak akan lebih cepat dari daerah viseral dibandingkan lemak daerah subkutan. Peningkatan asam lemak bebas akan merangsang pengeluaran hormon-hormon adipositokin seperti leptin, tumor 
necrosis faktor $\alpha$ (TNF- $\alpha$ ), interleukin-6 (IL-6), resistin dan penurunan adinopektin. Pengeluaran hormon adipositokin mengakibatkan peningkatan glukoneogenesis, menghambat reseptor insulin dan menghambat pengangkutan glukosa otot yang dapat menyebabkan terjadinya resistensi insulin serta nantinya dapat menyebabkan diabetes melitus tipe 2 .

Menurut penelitian ini, terdapat responden dengan diabetes melitus tipe 2 namun tidak mengalami obesitas sentral yaitu sebanyak 5 responden. Hal tersebut disebabkan karena responden tersebut kemungkinan mengalami obesitas sentral saat awal didiagnosa mengalami diabetes melitus dan obesitas sentral tersebut menurun seiring dengan lamanya menderita diabetes melitus tipe 2. Hal itu disebabkan karena proses pemecahan lemak. Sel tubuh yang tidak dapat menggunakan glukosa sebagai energi akan mengirim sinyal lapar ke otak dan kemudian mendorong seseorang untuk makan serta memenuhi kebutuhan energinya. Selain respon lapar, otak juga memerintahkan tubuh untuk melakukan pemecahan lemak dalam tubuh yang disebut proses lipolisis. Lemak akan diubah menjadi asam lemak dan gliserol serta menghasilkan keton. Proses pemecahan lemak yang terus menerus ini menyebabkan tubuh mengalami penurunan berat badan (Tortora \& Derrickson, 2012).

\section{Hubungan Aktivitas Fisik dengan Kejadian Diabetes Melitus Tipe 2}

Berdasarkan hasil ini, responden dengan diabetes melitus tipe 2 sebagian besar memiliki aktivitas fisik rendah yaitu 27 responden (52,9\%). Hasil analisis bivariat menggunakan uji Lambda dan diperoleh nilai $\mathrm{p}=0,041$ karena nilai $\mathrm{p}<\alpha(0,05)$, maka $\mathrm{H}_{0}$ ditolak. Hal ini berarti bahwa ada hubungan yang bermakna antara aktivitas fisik dengan kejadian diabetes melitus tipe 2 di Puskesmas III Denpasar Utara. Kuat lemahnya korelasi dilihat dari nilai $r$ yaitu 0,529 nilai tersebut menunjukkan korelasi yang sedang antara variabel aktivitas fisik dengan kejadian diabetes melitus tipe 2. Nilai koefisien korelasi bertanda positif ini menunjukkan bahwa semakin rendah aktivitas fisik responden maka semakin besar risiko terkena diabetes melitus tipe 2 di Puskesmas III Denpasar Utara dan begitu juga sebaliknya.

Hasil penelitian ini sesuai dengan penelitian Kawalot, Kandau dan Kalibu (2016) yang menyatakan bahwa terdapat hubungan yang signifikan antara aktivitas fisik dengan diabetes melitus tipe 2 dengan uji statistik menunjukkan nilai probabilitas ( $p$ value) sebesar 0,026 dengan tingkat kesalahan 0,05 ( $p$-value $<0,05$ ) dan diperoleh odd ratio (OR) sebesar 0,358 dengan Convidence interval (CI) 0,1430,899 . Hasil penelitian ini juga sesuai dengan teori yang menyatakan Pengambilan glukosa pada keadaan istirahat atau tidak beraktivitas membutuhkan insulin atau yang disebut insulin-dependent sedangkan pada saat otot aktif atau beraktivitas terjadi peningkatan pada kebutuhan glukosa tetapi kadar insulin tidak meningkat. Kurangnya aktivitas fisik juga menyebabkan penurunan aliran darah dan sedikit jala-jala kapiler yang terbuka sehingga menyebabkan berkurangnya ketersediaan reseptor insulin dan reseptor insulin menjadi lebih pasif (Sudoyo, Setiyohadi, Alwi, Simadibrata \& Setiati, 2009).

Menurut penelitian ini, terdapat 1 responden yang mengalami diabetes melitus tipe 2 namun memiliki aktivitas fisik tinggi. Hal tersebut disebabkan karena diabetes melitus tipe 2 disebabkan oleh berbagai faktor salah satunya adalah aktivitas fisik namun apabila aktivitas yang dilakukan tinggi tetapi responden 
DOI: $\underline{\text { https://doi.org/10.36376/bmj.v6i2 }}$

tersebut tetap mengalami diabetes melitus kemungkinan faktor resiko lain mempengaruhi terjadinya diabetes melitus tipe 2 seperti faktor keturunan.

Penelitian Wagner (2013) menunjukkan bahwa riwayat keluarga DM berhubungan secara signifikan dengan risiko terjadinya diabetes $(\mathrm{OR}=1,4$ dengan $95 \% \mathrm{CI}=1,27: 1,54, \mathrm{p}<0,001)$. Riwayat keluarga DM ini mempunyai peningkatan risiko untuk menderita diabetes sekitar $40 \%$ dan apabila ditambah dengan faktor obesitas dan umur maka akan meningkat sekitar $26 \%$. Besarnya pengaruh riwayat keluarga dimungkinkan karena adanya defek genetik sel $\beta$ pulau Langerhans, biasanya onset terjadinya hiperglikemia pada usia muda $(<25$ tahun), sekresi insulin minimal tanpa adanya kelainan pada aksi insulin. Selain itu dimungkinkan juga karena kelainan genetik pada aksi insulin, di mana terjadi kelainan pada insulin reseptor (American Diabetes Association, 2010).

\section{Simpulan}

\section{SIMPULAN DAN SARAN}

Berdasarkan hasil penelitian dan pembahasan yang peneliti lakukan dapat diambil kesimpulan sebagai berikut:

1. Hasil pengukuran lingkar perut menunjukkan dari 51 responden didapatkan bahwa sebagian besar responden mengalami obesitas sentral yaitu sebanyak 32 orang atau sekitar $62,7 \%$.

2. Hasil pengisian kuesioner GPAQ menunjukkan dari 51 responden didapatkan bahwa sebagian besar memiliki riwayat aktivitas fisik rendah yaitu sebanyak 29 orang atau sekitar $56,9 \%$.

3. Hasil analisis bivariat menggunakan uji Lambda untuk mengetahui hubungan obesitas sentral dan kejadian diabetes melitus tipe 2 didapatkan hasil nilai $\mathrm{p}=$ 0,031 karena nilai $\mathrm{p}<\alpha(0,05)$, maka $\mathrm{H}_{0}$ ditolak. Hal ini berarti bahwa ada hubungan yang bermakna antara obesitas sentral dengan kejadian diabetes melitus tipe 2 di Puskesmas III Denpasar Utara. Kuat lemahnya korelasi dilihat dari nilai $r$ yaitu 0,529 nilai tersebut menunjukkan korelasi yang sedang antara variabel obesitas sentral dengan kejadian diabetes melitus tipe 2. Nilai koefisien korelasi bertanda positif ini menunjukkan bahwa semakin obesitas sentral responden yang berobat maka semakin besar risiko mengalami diabetes melitus tipe 2 di Puskesmas III Denpasar Utara dan begitu juga sebaliknya

4. Hasil analisis bivariat menggunakan uji Lambda untuk mengetahui hubungan aktivitas fisik dengan kejadian diabetes melitus tipe 2 diperoleh nilai $\mathrm{p}=0,04$ karena nilai $\mathrm{p}<\alpha(0,05)$, maka $\mathrm{H}_{0}$ ditolak. Hal ini berarti bahwa ada hubungan yang bermakna antara aktivitas fisik dengan kejadian diabetes melitus tipe 2 di Puskesmas III Denpasar Utara. Kuat lemahnya korelasi dilihat dari nilai r yaitu 0,529 nilai tersebut menunjukkan korelasi yang sedang antara variabel aktivitas fisik dengan kejadian diabetes melitus tipe 2. Nilai koefisien korelasi bertanda positif ini menunjukkan bahwa semakin rendah aktivitas fisik responden maka semakin besar risiko terkena diabetes melitus tipe 2 di Puskesmas III Denpasar Utara dan begitu juga sebaliknya.

Berdasarkan hasil penelitian yang telah dilakukan di Puskesmas III Denpasar

Utara, diharapkan bagi Puskesmas III Denpasar Utara dapat memberikan penyuluhan ke banjar-banjar mengenai dampak dan bahaya penyakit diabetes melitus serta arti pentingnya pola hidup sehat agar terhindar dari diabetes melitus tipe 2. Selain itu bagi masyarakat yang tidak terdiagnosa diabetes melitus tipe 2 
DOI: https://doi.org/10.36376/bmj.v6i2

diharapkan dapat menjaga pola makan dan aktivitas fisiknya agar terhindar dari penyakit diabetes melitus tipe 2 dan bagi peneliti selanjutnya diharapkan agar dapat mengembangkan penelitian ini dengan menggunakan alat ukur yang berbeda terutama dalam mengukur riwayat aktivitas fisik agar dapat memastikan frekuensi, intensitas, dan waktu secara tepat.

\section{DAFTAR PUSTAKA}

American Diabetes Association. 2010. Diagnosis and Classification of Diabetes Mellitus. Diabetes Care Vol. 33. Available at: https://care.diabetes jour nals.org (17 Januari 2019)

Black \& Hawks. 2008. Medical Surgical Nursing: Clinical Management for Positive Outcome 8th ed..Amsterdam: Elsevier Science Health.

Dafriani. 2016. Hubungan Pola Makan dan Aktivitas Fisik Terhadap kejadian Diabetes Melitus di Poliklinik Penyakit Dalam RSUD dr.Rasidin Padang. Available at:https://ners.fkep.unand.ac.id (2 Januari 2019)

Dinas Kesehatan Kota Denpasar. 2017. Data Dinas Kesehatan Kota Denpasar. Denpasar: Dinas Kesehatan Kota Denpasar

Dinas Kesehatan Provinsi Bali. 2018. Data Dinas Kesehatan Provinsi Bali. Denpasar: Dinas Kesehatan Provinsi Bali

Flegal KM, Carroll MD, Ogden CL, Curtin LR. 2010. Prevalence and trends in obesity among US adults, 1999-2008. Https://ncbi. nih.gov/ pubmed/ 2007 1471 (24 Agustus 2018)

International Diabetes Federation. 2017. IDF Diabetes Atlas Eighth edition, International Diabetes Federation. Available at: https://www.idf.org (10 Agustus 2018)

Kawalot, Kandou, Kalibu. 2016. Hubungan antara aktivitas fisik dan riwayat keluarga dengan kejadian diabetes melitus tipe 2 pada pasien rawat jalan di wilayah kerja puskesmas tenga kecamatan tenga. Available at: https://portalgaruda.org (2 Januari 2018)

Kementerian kesehatan RI. 2014. infodatin-diabetes.pdf. Available at: https:// www. depkes.go.id (13 Agustus 2018)

Kronenberg, Williams. 2008. Texbook of Endocrinology. Available at: https://www.ncbi.nlm.nih.gov. (11 Januari 2019)

Nursalam. 2017. Metodologi Penelitian Ilmu Keperawatan 4th ed. Jakarta: Salemba Medika.

PERKENI. 2015. Pengelolaan dan pencegahan diabetes melitus tipe 2 di indonesia 2015. Available at: https://pbpperkeni.or.id (13 Agustus 2018)

Rusyadi. 2017. Pola makan dan aktivitas fisik mahasiswa dengan berat badan berlebih di universitas negeri yogyakarta. Available at: nttps://eprints.uny.ac.id (30 Desember 2018

Sudoyo, Setiyohadi, Alwi, Simadibrata, \& Setiati. 2009. Buku Ajar Ilmu Penyakit Dalam. Jakarta: Interna Publishing

Susilawati, Muljati, Krisnawati. 2011. Perbandingan IMT dan indikator obesitas sentral terhadap kejadian diabetes melitus tipe 2. Available at: https://ejournal.litbang.depkes.go.id (2 Januari 2019) 
DOI: $\underline{\text { https://doi.org/10.36376/bmj.v6i2 }}$

Salim, Aji. 2014. Faktor-faktor yang berhubungan dengan kejadian obesitas pada karyawati sekretariat daerah kabupaten wonosobo. Available at: https:// https:// ejournal.litbang.depkes.go.id (30 Desember 2018)

Tortora \& Derrickson. 2012. Principle of Anatomy and Physiology. USA: John Wiley and Sons Inc

Trisnawati \& Soedijono. 2013. Faktor resiko kejadian diabetes melitus tipe 2 di puskesmas kecamatan cengkareng Jakarta Barat. Available at:https:// ejournal.litbang.depkes.go.id (1 Januari 2018)

Wagner. 2013. Family history of diabetes is associated with higher risk for diabetes: a multicentre analysis from the German Center for Diabetes Research. Available at: https://link.springer.com (17 Januari 2019)

Widastra. 2015. Obesitas Sentral sebagai Faktor Penyebab Timbulnya Resistensi Insulin Pada Orang Dewasa. Available at: https://www.poltekkesdenpasar.ac.id (29 Desember 2018) 